\title{
PRESCRIPTION OF TITLE TO CHATTELS
}

\author{
J. E. COTE*
}

There is little direct authority for the statement that the Statute of Limitations bars only the remedy but does not affect the title to chattels. $M r$. Côté concludes that, as "ownership" of a chattel is the sum of rights possessed with respect to it, when the rights in tort are extinguished, so also is ownership. This is in line with the objects of the statute.

Since 1623 the law of England has contained sweeping statutory provisions designed to avoid the litigation of stale claims at a time when the necessary evidence has become lost and men's memories blurred. The original Statute of Limitations ${ }^{1}$ simply forbade the bringing of a number of specified actions more than a certain length of time after the cause of action arose. One of the most important questions raised by any limitations statute is what effect such a provision has on title $^{2}$ to property, once the time for bringing an action for its recovery has expired. Statutes have long since made it clear that the title of the original owner of real property is extinguished if the owner fails to sue for its recovery within the statutory period, and the 1939 revision of the 1623 statute in England ${ }^{3}$ makes such a provision for personal property as well. But only one of the Canadian common-law provinces has passed such an enactment, and the law in the rest stands as it did in England before passage of the 1939 statute. ${ }^{4}$ Do limitation of actions statutes extinguish title to chattels? If they do not, what remedies does the dispossessed owner of the chattel have when his right of action has been lost?

In Alberta, the relevant statute ${ }^{\sigma}$ is almost completely silent on this point. Indeed, the following is all that the statute says about chattels:

2. In this Act,

(a) 'action' means a civil proceeding;

51. Except as otherwise provided in this Part, an action for . . .

(f) trespass or injury to real property or chattels, whether direct or indirect and whether arising from an unlawful act or from negligence or from breach of a statutory duty, or

(g) the taking away, conversion or detention of chattels,

may be commenced within two years after the cause of action arose, and not afterwards. ...

57. Where the existence of a cause of action to which this Part applies has been concealed by the fraud of the person setting up this Part as a defence, the cause of action shall for the purposes of this Part be deemed to have arisen when the fraud was first known or discovered.

- B.A. (McGill), LL.B. (Alta.), B.C.L. (Oxon.), of the Alberta Bar.

My warmest thanks are due to Professor W. F. Bowker and to Professor D. J. Sherbaniuk for having read the entire draft of this article and offering copious comments, corrections, and references. But of course they have not been able to eliminate all the errors, and they do not subscribe to all the heresies contained in the article.

1 (Imp.) 21 Jac. 1, c. 16, s. 3.

2 Although some authors (such as Salmond) give "title" a special meaning, here it Just means ownershtp generally.

8 Limitation Act, 1939 (Imp.) 2 \& 3 Geo. 6, c. 21, s. 3.

4 Limitation of Actions Act, R.S.A. 1955, c. 177, s. 51 (f), (B) (See S.A. 1966, c. 49); Statute of Limitations, R.S.B.C. 1960, c. 370, s. 3; Limitation of Actions Act, R.S.M. 1954 , c. 145, s. $3(1)$ (e); Limitation of Actions Act, R.S.N.B. 1952, c. 133, ss. 9, 61; Limitation of Actions (Personal) Act, R.S.Nfld. 1952, c. 146, s. 2; Statute of Limitations, R.S.N.S. 1954, c. 153, s. $2(3)$; Limitations Act, R.S.O. 1960, c. 214, s. 45(1) (g); Statute of Limitations, R.S.P.E.I. 1951, c. 87, s. $2(\mathrm{~g})$; Limitation of Actions Act, R.S.S. 1965 , c. 84 s. $3(1)(e)$. Section $61(2)$ of the New Brunswick statute extingulshes title to the chatteis after the time has. run. These statutes are here referred to compendiously as "the Statute of Limitations."

supra, n. 4. 
Statements that title to personalty is not extinguished by limitations statutes are commonly found in textbooks and reference works, ${ }^{\circ}$ but closer examination will reveal that there is very little in the way of direct authority in the decided cases for these statements. What is more, these works give no guidance as to what the rights and remedies of the dispossessed person and the wrongdoer would be once six years had elapsed, though these are vital, for a man who has no practical means of recovering his chattels or their worth will derive little comfort from assurances that he is still their owner. A more thorough examination of the authorities is therefore necessary, and we may with profit begin by a consideration of the nature of ownership of chattels.

Whatever may be the theoretical basis at common law for ownership of land, English law offers no consistent theory of the ownership of personal property. ${ }^{\top}$ The underlying bases of the ownership of chattels are most unclear. The law of personal property tells what rights the courts will enforce with respect to personal property, yet each lawsuit results in a decision only as to the relative merits of the two litigants before the court. The superior rights of persons not parties cannot be raised: ${ }^{8}$ it matters not that a third party has a far better claim to the goods than either of the parties before the court. As a result, the law of personal property consists only of a body of rules as to when and against whom one may successfully assert one's rights with respect to the personalty. English law never declares that a person is the owner of a chattel or even of any notional estate in it: the law declares only that he has a better claim to possess and enjoy the goods than does some other person. Therefore, there is much to be said for the proposition that the notion of title or ownership has no place in the law of personal property. ${ }^{9}$

A striking example is provided by the leading case of Armory v. Delamirie. ${ }^{10}$ The plaintiff Armory, who had found a valuable jewel, was able to recover it from the defendant to whom he had momentarily lent it and who refused to return it to him, and the court declared that the plaintiff as finder had a right to the jewel as against all the world except "the true owner." Yet it is clear that if someone had demanded the jewel from Armory, claiming that he (the claimant) was "the true owner," all that he would have had to show was that it was he who had lost the jewel, and that vis-à-vis him Armory had no right to keep it. It would matter not that this "true owner" was himself a mere prior finder or (probably) even a thief. Yet once remove the "true owner," and Armory then has a better right than anyone else, and becomes "owner" on anyone's test, though he is a mere finder.

Therefore, we must conclude that ownership of a chattel will be found only by weighing and comparing the rights which various individuals have in respect to the chattel. He who can (subject to the general rules of torts and criminal law) exercise all possible rights with respect to a

- See, for example. Preston and Newsom, Limitation of Actions 41 (3d ed. 1953); Paton, Bailment in the Common Law 420 (1952); Williams on Personal Property 25
(16th ed. 1906); Salmond, Torts 282 (13th ed. 1961); and a dictum in In re Alison (1879) 11 Ch.D. 284, $295-96$ (C.A.)

7 Vaines, Personal Property 39-41, 43 (3d ed. 1962). Williams, op. cit. supra, n. 6, at $10 \mathrm{ff}$.

8 The Winkfield, [1902] P. 42 (C.A.); unless of course, the defendant himself claims under the ius tertii: Eastern Construction Co. v. National Trust Co., [1914] A.C. 197; cf. Glenwood v. Phillips, [1904] A.C. 405, and Wilson v. Lombank, (1963) 1 W.L.R. 1294 (Q.B.D.).

o Note how little right in the victim suffices for theft: Rose v. Matt, [1951] $1 \mathrm{~K} . \mathrm{B}$. 810 (C.C.A.).

10 (1722), 1 Stra. 505; 93 E.R. 664. 
chattel, using it, destroying it, alienating these rights, or passing them on to his personal representative without fear of suit by anyone else, must be considered the "owner." For the present inquiry, this notion of ownership will suffice. The law does not require a person seeking any remedy with respect to a chattel to show that he has ownership in any absolute sense, ${ }^{11}$ or in any abstract sense, apart from specific rights with respect to it, such as the right to use it or possess it or exclude others. It is sometimes asserted, for instance, that in a suit for detinue (as opposed to trover) the plaintiff must show "title" to the goods.12 It will be found, however, that the cases do not bear this out, ${ }^{13}$ and that just as is the case with respect to conversion, the plaintiff may recover the chattel in detinue by demonstrating a superior right to possess the chattel.

Any notion of "true ownership" or "absolute title" to chattels beyond what is set out above lacks any basis in the actual rules of English law. ${ }^{14}$ The highest right to a chattel known to our system of law is a better right to possess than anyone else can assert. The point is that the parties to a suit need never look beyond the relative strength of their two claims. One who sues another to enforce a patent must often prove that his patent is valid, i.e. prove his title to it against all the world. But one who sues another to assert rights to a chattel need not show any particular degree of right in himself: all he need show is that the defendant has less right to the chattel than he has. Indeed, no one can show any more.

This may well stem from the fact that (unlike Roman law) English law has no form of suit to test ownership of chattels. ${ }^{13}$ One can only assert a specific right against one specific person; one cannot assert the totality of rights which is ownership. ${ }^{16}$ One can only claim for the infringement of a contractual right with respect to a chattel, or sue in respect of a tort done to a chattel. If everyone who is likely to interfere with one's chattel would be liable in contract, tort or equity for doing so, then one has as much ownership as one can ever have in a chattel.

It is against this backdrop that the Statute of Limitations and its Canadian successors operate. The statutes do not (in their original form) refer to "title" or "ownership" of chattels or personalty, but they do provide that actions for trespass or injury to, or the taking away, conversion or detention of chattels shall not be brought more than a certain time after the cause of action arose. ${ }^{16}$ This has been interpreted uniformly as meaning that the person dispossessed cannot bring any action whatever in respect of the chattels against the original dispossessor more than six

11 As did the real actions in Roman law: see infra, $n$. 15 .

12 This seems to be what is meant by 33 Halsbury's Laws 62-63 (2d ed.), but the cases cited there do not bear out the proposition: Makepeace v. Jackson (1813). 4 Taunt.
770, 128 E.R. 534 (C.P.) turned on the plaintiff's lack of possession, not title; 770,128 E.R. 534 (C.P.) turned on the plaintiff's lack of possession, not title;
Crocker v. Molyneux (1828). 3 Car. \& P. 470, 172 E.R. 506 (K.B.) turned on the plaintiff's lack of a right to the goods vis-a-vis the defendant; Melling v. Kelshaw (1830), 1 C. \& J. 184, 148 E.R. 1385 (Ex.) turned on who had a right to possession. for neither party had possession; de Lizardi v. Pennel (1856), 6 El. \& B1. 742, 119 E.R. 1041 (Q.B.) also turned on the plaintiff's lack of possession; the same was true of Langton v. Higgins (1859), 4 H. \& N. 896, 157 E.R. (Ex. Ch.) and of Kearry v. Pattinson, I1939] 1 K.B.471 (C.A.); and of Gaudry v. C.P.R. (1896) 11 Man. $R$. 69; and of Jarvis v. Williams, [1955] 1 All E.R. 108 (C.A.). If title were necessary for a suit in detinue, the defendant would be able to raise a ius tertii, which it is clear he cannot; Supra, n. 7 .

13 See supra, n. 12.

14 Of course in theory there is an allodial right to chattels but not land, but that is another matter and of little practical effect anyway.

157 Holdsworth, History of English Law 465 (1925); but cf. Jenks, A Blind Spot in English Law (1933), 49 L.Q.R. 215, 217. For a debate as to how different Roman law really was in this respect, see Buckland and McNair, Roman Law and Common Law, Ch. 3 (2d ed. Lawson).

16 Statute of Limitations, supra, n. 1; see also supra, n. 4. 
years after the original conversion. ${ }^{1 i}$ But can he later sue other persons if they convert the same goods? Can he use other means to regain the goods from the original dispossessor? May he treat the goods as his own if they come peacefully back into his hands at some time in the future? A careful examination of the English and Canadian authorities does little to answer these questions.

Any review of the authorities must begin with a trio of cases very frequently cited for the proposition that the Statute of Limitations does not extinguish ownership of chattels. These are Spackman v. Foster, ${ }^{18}$ Wilkinson v. Verity, ${ }^{19}$ and Miller v. Dell. ${ }^{20}$ The first of these cases is usually said to show that the running of the statutory period does not extinguish the dispossessed person's ownership, for after it has run he can still demand the return of the goods and sue in detinue if he meets with a refusal. In fact, however, in that case the objects in question had been held for more than six years only on deposit, and so there had been no tort or adverse possession at all, and no right of action existed to start time running until the demand for their return was made. It is of course an elementary proposition that only tortious possession could give rise to any possible claim to prescription under the statutory provisions in question here. ${ }^{21}$ Salmond points out the absence in that case of any tort at all until the demand. ${ }^{22}$ Precisely the same was true in Miller v. Dell, ${ }^{23}$ which also involved the deposit of title deeds, but with the added factor that the defendant there had held them for less than the statutory period. Lord Esher M.R. did say there that the Statute did not bar title, but that was the purest dictum.

Several English and Canadian cases ${ }^{24}$ express the proposition that there is no Statute of Limitations applicable to personalty, but this is of course not strictly true, for the Acts do mention injury to or taking away of personal property. All that the courts mean by that proposition is that mere lapse of time or holding of property does not of itself start time running, for only a tort does that; in other words, the possession must be adverse. ${ }^{25}$

Wilkinson v. Verity ${ }^{26}$ is different from Spackman v. Foster and Miller v. Dell, for there the defendant had converted the goods by selling them more than six years before the action was brought. However, the court explicitly affirmed the general rule that once a cause of action has accrued to the plaintiff, no other subsequent acts by him will start time running again, and all such rights of action are barred six years from the first tort. ${ }^{27}$ The court distinguished the facts in Wilkinson from those

\footnotetext{
17 Preston and Newsom, op. cit. supra, n. 6, at 42.

18 (1883), 11 Q.B.D. 99; 52 L.J.Q.B. 418 .

19 (1871), L.R. 6 C.P. 206; 40 L.J.C.P. 141

20 (1891] 1 Q.B. $408 ; 60$ L.J.Q.B. 404 (C.A.)

21 Clayton v. LeRoy, [1911] 2 K.B. 1031, 1048 (C.A.); Brown. Personal Property 36 (2d ed. 1955); Paton, op. cit. supra, n. 6, at 420; Jenks, loc. cit. supra, n. 15 at 224-25; The rule for realty may be different now, but the statutes in question say of chattels only that one cannot after two or six years sue for trespass, injury, taking away, conversion, or detention. These are all torts. The Acts do not refer to sults to "recover" chattels.

22 Salmond, Torts 261 (12th ed. 1957), or at 283 (13th ed. 1961). There is nothing contrary in Clemens v. Brown (1960), 22 D.L.R. (2d) 545, 548, (S.C.C.).

23 Supra, n. 20

24 London \& Midland Bank v. Mitchell [1899] 2 Ch. 161; In re Stucley [1906] 1 Ch. 67 (C.A.); McGregor v. Curry (1913), 31 O.L.R. 261, 270 (Ont. C.A.); Weld v. Petre, [1929] 1 Ch. 33 (C.A.).

25 See supra, $n$. 21. And in any event the cases in $n .24$ involved incorporeal personalty, not chattels. See Jenks, loc. cit. supra, $n .15$, at 218.

26 Supra, n. 19.

27 Cf. Limitation of Actions Act, R.S.N.B. 1952, c. 133, s. 61 (1).
} 
in ordinary cases on the ground that the defendant there was a bailee, which gave the plaintiff an option of suing when the sale was made, or of electing to wait and sue only after a demand and refusal (on the theory the defendant could not be heard to plead that he had earlier disabled himself from returning the goods.) Therefore, this case, by the court's own reasoning, has no application to the ordinary situation where the defendant is not a bailee or fiduciary.

Thus neither Spackman, Wilkinson, nor Miller throws any light on whether the running of time after a tort to goods bars only the remedy, or whether it also extinguishes the victim's ownership of the goods. These cases deal only with the question of when time starts to run. But one would think that if the first tort sets time running irrevocably and later "torts" do not give rise to a new time in which to sue, then it is more likely that the title is being extinguished, and not merely the remedy of suit.

As the English cases on point seem to offer little help, we must review carefully the statements of English writers on the subject, to see what grounds are urged for their oft-repeated statement that the Statute of Limitations only bars the remedy, and does not affect the right to the chattels.

Pollock and Wright" suggest that "a true owner who peaceably retakes his goods, after being out of possession for however long a time, may hold them as in his former right against all the world." From the context it is clear that they have in mind the owner whose right of action has become statute-barred. Yet no authority whatever is given for this proposition, and on the next page it is asserted that an owner in this position could not retake his goods by force, because he would have no right to demand his goods' return, this having been lost by the running of time. (A statement by Jessel M.R. in Ex parte Drake ${ }^{29}$ is given as authority for this proposition, though there was no question of limitation periods there.) It is submitted that this chain of reasoning should lead to the conclusion that the running of time would bar the right to peaceful recaption just as much as recaption by force. In any event, Pollock and Wright offer no argument or authority for their statement to the contrary.

Williams $^{30}$ also suggests (with a little less certainty) that the Statute of Limitations does not extinguish title to chattels, because the right of recaption appears not to be affected, and because a right of recaption implies ownership. ${ }^{31}$ As authority for the existence of the right of recaption, Williams cites the above-mentioned passage from Pollock and Wright, together with one from Littleton. ${ }^{32}$ Littleton, of course, wrote long before the Statute of Limitations was passed, and he only said that a release of personal actions did not take away a right of recaption of one's chattels. This passage in Littleton may possibily be explained as turning on a strict interpretation of the release itself, in which case

28 Possession in the Common Law 114 (1888).

29 (1877), 5 Ch.D. 866, 868, 46 L.J.Bky. 105. This case simply held that an unpaid judgment in detinue does not transfer title, though the plaintiff should get an order for return of the chattel, and not simply direct its seizure.

30 Op. cit. supra, n. 6, at 25 .

31 Citing Y.B. 5 Hen. $8,15,16, \mathrm{pl}$. 6, for this last proposition.

32 "498. Also if I have any cause to have a Writ of Detinue of my Goods agalnst another, albeit that I release to him all Actions personal, yet I may by the Law take my Goods out of his possession, because no Right of the Goods is released to him, but only the Action, \& c." 
we would do well to remember that the Limitation of Actions Act is to receive a fair, large, and liberal construction in order to attain its ends. $^{33}$ But in any event, it is obvious that there is no close analogy between a statute of limitations designed to prevent the litigation of stale and dubious claims of all kinds (whether for damages or for the return of goods), and a release of "actions personal."

Branston ${ }^{84}$ thinks that the Statute of Limitations does not take away the right of recaption of chattels, but he gives no direct authority for the statement beyond the above-mentioned passages from Littleton, and Pollock and Wright.s5 Against the view that recaption only does indirectly what a lawsuit does directly, he offers only the statement that self-help has always been an addition to, and not an alternative to, the judicial remedies. He thus favors the view that recaption is an incident of ownership and enjoyment and not a mere remedy. But this does nothing to answer the basic question, whether the limitations statutes extinguish ownership. By assuming that the incident of ownership (recaption) still exists, he assumes ownership still exists and so begs the question.

Holdsworth ${ }^{36}$ also concluded that the title to chattels is not barred by the Statute of Limitations, but he reached this conclusion by observing that because a special statute was expressly passed in 1833 to make the running of time extinguish title to land, the lack of such a statute for chattels means title is not barred. But this is a non sequitur, for he assumed that the Statute of 1623 did not itself extinguish ownership to chattels, which is the very question in issue. That before 1833 the courts had held ownership of land was not extinguished is not conclusive, for as we have seen before, there is really no such thing as absolute ownership of chattels: one can have no higher right to a chattel than to possess it clear of any right to possession in any other person. It is by no means certain that that is true of land. For authority, Holdsworth cited Pollock and Wright, and Miller v. Dell, ${ }^{37}$ but as we have seen above, that case is clearly distinguishable. ${ }^{38}$ He noted that Salmond ${ }^{30}$ was of was of the opinion that the running of time in effect transferred title, and he agreed that this was a desirable rule of law. ${ }^{40}$

Salmond's view ${ }^{41}$ that a right of recaption exists only where there is also a right to recover the goods by judicial proceedings was adopted by the Saskatchewan Court of Appeal in Phillips v. Murray, ${ }^{42}$ a suit for assault arising from a forcible recaption. Cowan ${ }^{43}$ finds the Saskatchewan case not consonant with the "true state of the law," according to which he believes ownership of chattels not to pass with the running of time. In addition to the authorities cited above, he also cites a number

\footnotetext{
33 Interpretation Acts: S.A. 1958, c. 32, s. 11; R.S.B.C. 1960 , c. 199, s. $23(f)$ : S.M. 1957, c. 33, s. $13 ;$ R.S.N.B. 1952 , c. 114 , s. $17 ;$ R.S.Nfld. 1952 , c. 1, s. 17; R.S.N.S 1954 , c. 136 , s. 8(5); R.S.O. 1960, c. 191, 8. 10; R.S.P.E.I. 1951, c. 1, s. 14 ; R.S.S.

84 The Forcible Recaption of Chattels (1912), 28 L.Q.R. 262, 272.

35 Supra, nn. 28, 32.

307 Holdsworth, op. cit. supra, n. 15, at 464, 511.

37 Supra, n. 20.

38 There is a dictum in the case supporting his position, but it is contrary to dicta in Clayton v. LeRoy, supra, n. 21, and Elwes v. Briggs Gas Co. (1886), 33 Ch.D. $562,568$. See also the authorities collected by Ames, infra, $n$. 53 39 Torts 331 (3d ed. 1912), cf. supra, n. 6 . 40 Holdsworth, op. cit. supra, n. 15, at 464 n. 8. 41 Salmond, Torts 211 (6th ed. 1924).

42 [1929] 3 D.L.R. 770

48 (1981), 9 Can. Bar Rev. 461.
} 
of cases $^{44}$ dealing with the imperfect prescriptive effect of the Statute of Limitations on debts. This is an analogy which may be of limited use, for choses in action are not chattels capable of possession or apparent ownership, and can physically be the subject only of extinctive prescription, not acquisitive prescription. ${ }^{45}$ In other words you can in fact deprive your creditor of his debt by not paying him, but it is very difficult to steal a debt from another and hold it. Cowan points out that $E x$ parte Drake ${ }^{46}$ dealt with transfer of ownership of chattels by satisfaction of a judgment for detinue and so is not a direct authority on the Statute of Limitations, but he does nothing further to refute the general principle expressed in that case, that when a right can no longer be enforced by action, it can no longer be exercised. He also quotes Mellersh v. $B r o w n^{47}$ as establishing the undoubted proposition that the provisions of the $1833 \mathrm{Act}^{48}$ do not apply to personalty, which is nothing to the point at all.

Cowan also quotes In re Hepburn, ${ }^{49}$ which raises a certain contradiction in the argument that the Statute of Limitations does not extinguish ownership of chattels. That case supports the proposition (to which we will refer later) that a right shorn of all its remedies has in point of fact ceased to exist. It is said, however, that ownership has not been ended by the Statute because one of the remedies, recaption, still exists. Yet as seen before, Branston rests his case on the view that recaption is "something essentially different in its nature from, and not merely an alternative to the judicial remedies available," and Cowan adopts this view. ${ }^{\text {so }}$ Thus at one moment Cowan says ownership still exists because a remedy (recaption) still exists to enforce it, and at another moment he says it exists unscathed by the prohibition of the Statute on actions only because its exercise (recaption) is not a remedy, but an incident of ownership, i.e., one of the very rights of which ownership is composed.

The answer to this contradiction is simply that in English law, "ownership" of a chattel is the sum of the rights ${ }^{\text {s1 }}$ possessed with respect to it, that these rights consist of, or are protected by, the ability successfully to bring a suit in tort in defence of the chattel,52 and when these rights in tort are gone "the right has in point of law ceased to exist." English law property rights in a chattel flow from the rules of tort applicable to it: when the right to sue in tort is gone, the ownership is

44 Williams v. Jones (1811), 13 East 439; 104 E.R. 441: Bryson v. Graham (1849), 1 N.S.R. 271; Carvell v. Wallace (1873) 9 N.S.R. 165; Higgins v. Scott (1831), 2 B. \& Ad. 413; 109 E.R. 1196 (K.B.); Courtenay v. Williams (1844), 3 Hare 539; 551; 67 E.R. 494, 499; Spears v. Hartly (1802), 3 Esp. 81; 170 E.R. 545; In re Hepburn (1884), 14 Q.B.D. 394, 399.

45 of course a bearer note or bond may be possessed or lost or found or stolen, but this is quite beside the point. The cases cited by Cowan deal with enforcing the chose in action against the promisor after six years, not who can enforce it if it is enforceable. The question of who owns the chose in action is quite separate from is enforceable. The question of who owns the chose in action is quite separate from
whether it is of any legal effect against the promisor. One could have perfect whether it is of any legal effect against the promisor. One could have perfect
prescription (shift of ownership) for one purpose, but not the other. On possession prescription (shift of ownership) for one purpose, but not the other. On possession
of incorporeal things, see Salmond, Jurisprudence 320-21, 340-43 (11th ed. Williams 1957).

46 Supra, n. 29.

47 (1890), 45 Ch.D. 225, 229; 60 L.J.Ch. 43, where a provision as to charges on realty and interest on them was held inapplicable to personalty.

$483 \& 4$ Wm. 4, c. 27, s. 34 .

49 (1884), 14 Q.B.D. 394, 399.

50 Loc. cit supra. 45 , at 466 n. 30.

51 "Rights" here includes Hohfeldian powers, immunities, and liberties, of course.

52 Supra, n. 15 .

52 Supra, n. 15. Harv. L. Rev. 23, 313, 337, at 319 . "An Immortal right to bring an eternally prohibited action is a metaphysical subtlety that the present writer cannot pretend to understand." 
gone. Meanwhile the person who now has possession can maintain these same rights against all the world, for no one with a right to sue him in tort exists. It is because these rights in tort are the only proprietary rights with respect to chattels, that limitation of actions produces acquisitive prescription with respect to chattels, and not with respect to realty. ${ }^{54}$ This is precisely the conclusion reached by Ames in his famous article, The Disseisin of Chattels, ${ }^{55}$ and he reinforces his conclusion with the citation of numerous English authorities. ${ }^{56}$

This reasoning is supported by a modern decision of the Privy Council, Singh v. Ali. ${ }^{\text {st }}$ There the defendant sold a truck to the plaintiff without a permit, so that the sale was illegal and void. But the plaintiff took possession under the sale, and when later the defendant seized the truck back from him, sued successfully in detinue. The Privy Council upheld the plaintiff's right to sue, sayingss that though the sale was void, the defendant (as a party to the illegality) could not be heard to assert his claim to the truck in court. Therefore, as the plaintiff had had possession and no one could assert a better right to the truck, the plaintiff must be the "owner." The analogy to the Statute of Limitations is close, if we substitute for the original void sale from the defendant to the plaintiff, a conversion of the defendant's truck by the plaintiff more than six years before. Then the prohibition against suing to take advantage of one's own wrong would correspond to the statutory prohibition against suing after six years had passed. The result in that event must be the same, for the Privy Council has said that once the original "owner" loses his right to sue to enforce his title, the person with possession becomes the "owner." This is a striking confirmation of Armory v. Delamirie. ${ }^{59}$

However, lest it be felt that the foregoing appeal to authority is not a fitting foundation for the interpretation and development of law today, we may consider which rule of law would be more expedient. Limitations statutes have two main objects: they encourage prompt settlement of suits, so as to minimize the unsettling effects of drawn-out disputes; ${ }^{\text {Bo }}$ and in addition, they prevent titles being disturbed by claims made long after memories have faded and documents been lost or destroyed, on the theory that such stale claims usually are unjust. ${ }^{61}$ Experience has shown that few people can prove a long chain of title to any of their property, and this is even more true of chattels than of land. One who has openly possessed a thing for a time is probably the owner. ${ }^{02}$ Besides, many people assume this is so, and their expectations must not be rudely upset, lest innocent purchasers and lenders be harmed. ${ }^{63}$ In short, limita-

64 This is the distinction Holdsworth makes, but does not carry through to its logical conclusion, and which Cowan misses entirely.

58 (1890), 3 Harv. L. Rev. 23, 313, 337, at 318-20.

60 Bract. 52a; 2 Bl. Com. 196 (speaking only of realty, though written before 1833) 3 Bl. Com. 196 (speaking of pre-1833 limitations statutes as to land): 1 Hayes, Conveyancing 270 (5th ed.); Stokes v. Berry (1699) 2 Salk. 421, 91 E.R. (K.B.); Co. Litt. 239a (speaking also of land); Taylor v. Horde (1757) I Burr. 60, 119; 97 E.R. 190 (K.B.) 223 (ditto); Cholmondeley v. Clinton (1820) 2 Jac. \& W. 1, 156; 37 E.R. 527, 583 (Ch.) (ditto).

$57[1960]$ A.C. 167 (P. C. (Malaya) ).

68 Id., at 176-77, per Lord Denning.

59 Supra, n. 10.

60 Salmond, op. cit. supra, n. 45 at 477; Developments in the Law: Statutes of Limitations (1950), 63 Harv. L. Rev. 1177, 1185.

01 Brown, Personal Property 35 (2d ed. 1955); Developments, etc., supra, $n .60$, at 1185. 62 Salmond, op. cit. supra, n. 45 , at 476.

(s Brown, op. cit. supra, n. 61, at 35. 
tions statutes are what American writers call "statutes of repose." These aims cannot be fully realized unless these statutes are interpreted as transferring title once the time has run.

Indeed, American courts have uniformly interpreted the 1623 Statute of Limitations as doing just that.. ${ }^{65}$ Both Chief Justice Marshall ${ }^{66}$ and Oliver Wendell Holmes ${ }^{6 \tau}$ accepted this view of the law as the only one consonant with the objects of the Statute. Otherwise no property would ever be safe from stale claims based on long-forgotten and dubious transactions. ${ }^{\circ}$ It is almost certainly this kind of reasoning which has moved the United Kingdom Parliament to introduce legislation in 1939 to the same effect. ${ }^{\text {o }}$

It would be most beneficial if Canadian courts would interpret the limitations statutes the same way, but may this be too much to hope for? They have usually been reluctant to give too wide an interpretation to such legislation. In particular, in many other fields they have held these Acts bar the remedy but not the right. Thus they have held a statutebarred debt still exists, and that may well be why a statute-barred debt may be revived by a simple acknowledgement. ${ }^{70}$ An executor may pay a statute-barred debt of the estate ${ }^{i 1}$ (though testamentary release of such a debt has been held bounty), ${ }^{72}$ and so a creditor coming into possession of his debtor's funds as executor may lawfully retain statutebarred claims for conversion or detinue of chattels.

But to do that would raise many perplexing problems. It has been settled that the first conversion or detinue sets time running, and no subsequent wrongful act by the same person will start a new time period running. ${ }^{3}$ Would that be true of wrongful acts by a third party? If after the time had run the original wrongdoer sold the goods to a third party, could the original owner sue the third party for conversion? If the sale took place before the original statutory period had run, how long would the original owner have to sue in respect of the second conversion? If the original owner could not sue the original tortfeasor once time had run, how could he sue his assignee? Or does the original tortfeasor obtain any sort of right he can sell? Then could anyone sue a thief who stole the goods from the original tortfeasor after the statutory period had run? Many other such conundrums might be put.

The most important question of all, though, is whether the original owner might just seize his goods wherever he found them, no matter how many years had gone by. Suppose your binoculars are stolen, and ten years later you notice that the person next to you at a football game has your binoculars. May you snatch them up when his back is turned? The answer depends on whether recaption is a mere remedy ancillary to ownership, or whether it is one of the inalienable rights of an owner,

o4 Id., quoting Garrett v. Vaghan (1873), 1 Baxt. 113 (Tenn.): A'Court v. Cross (1825) 3 Bing. 329, 332-33; 130 E.R. 540, 541-42 (C.P.): Cholmondeley v. Clinton, supra, n.

65 Brown, op. cit. supra, n. 61, at 33, who cites many American cases for this proposition. o6 Brent v. Chapman (1809), 5 Cranch. 358, 9 U.S. 200.

67 Chapin v. Freeland (1886), 142 Mass. $383 ; 8$ N.E. 128 (Sup. Jud. Ct. Mass.).

68 Brown, op. cit. supra, n. 62, at 33; Developments, etc., supra, n. 60, at 1249. On the evils of recaption, see infra, $n .75$.

69 Supra, n. 3.

70 This is not entirely clear, though: see the speech of Lord Sumner in Spencer $v$. Hemmerde, [1922] 2 A.C. 507 (H.L. (E.) ). G. 415; 65 E.R. 182; Re Green Est., [1932] 3 1 Stahlschmidt v. Lett (1853), 1 Sm. \& G. 415; 65 E.R. 182; Re

72 Re Fletcher. [1936] 2 All E.R. 236.

78 Supra, n. 27. 
that of doing as he pleases with his property. Either view is quite logical, ${ }^{74}$ and so the real choice is one of policy. It is bad enough that people be able to raise stale claims in the law courts; how much worse must it be that they use hired thieves, or private bailiffs, to do so? If the rare jewel you buy was stolen from a temple idol centuries before, must you live in a fortified castle to prevent its forcible recovery by the successors of the original owner? If recaption of chattels were allowed, either force or fraud would be the final arbiter. Can that be proper? Must one protect one's property with machine guns?is Surely that would allow the uncertainty and contention which law and courts themselves exist to prevent. Are not the English and American ${ }^{70}$ answers compelling?

But although England and the United States have so clearly pointed out the dilemma and its solution, the Canadian law has not advanced. Only one Canadian province ${ }^{77}$ has passed legislation along English lines to remove these doubts and avoid the possibility that Canadian courts might follow the modern writers' oft-repeated statement that the statute bars only the remedy and not the right. Is it not high time that the other provinces avoid this possibility by enacting a similar provision, to the effect that the title to goods is lost when the right to sue for their conversion or detention is lost?

74 Though it is hard to see how both views can be held simultaneously: supra, nn. 49,50 5 The licensed burglary likely to result is vividly portrayed in a novel by Rober Graves entitled Antigua, Penny Puce.

76 See supra, n. 66.

77 New Brunswick: supra, n. 4. (But with respect to redemption of mortgaged personalty note the statutory provision relied on in Warren v. People's Finance Corp. (1961) 36 W.W.R. 627 (Man. C.A.).) 